\title{
EFFECTS OF ALUMINUM CONTENT AND HEAT TREATMENT \\ ON GAMMA PRIME STRUCTURE AND YIELD STRENGTH OF
} INCONEL NICKEL-CHROMIUM ALLOY 706

\author{
E. L. Raymond and D. A. Wells
}

Huntington Alloy Products Division

The International Nickel Company, Inc.

\section{ABSTRACT}

An intermediate heat treatment at $1550^{\circ} \mathrm{F}$ used to improve the rupture ductility of INCONEL* alloy 706 had a varied effect on room-temperature yield strength of the alloy. The effect seemed to depend on very small differences in aluminum content.

A laboratory investigation was conducted to determine the effects of variations in aluminum content and heat treatment on the yield strength of alloy 706. Samples having aluminum contents from $0.033 \%$ to $0.90 \%$ were studied after being subjected to four different heat treatments. The investigation produced an explanation of the variations in yield strength in terms of changes in structure of gamma prime, gamma prime/ lattice mismatch, and changes in modulus of elasticity.

It was found that material age-hardened without the intermediate treatment is in a slightly underaged condition, and that yield strength of such material is a function of gamma prime particle properties. It was also found that material given the $1550^{\circ} \mathrm{F}$ intermediate treatment and then age-hardened is slightly overaged. The yield strength of overaged material is not a function of gamma prime properties but depends instead on matrix shear modulus and interparticle spacing of the gamma prime.

\section{INTRODUCTION}

INCONEL nickel-chromium-iron alloy 706 is a relatively new precipitation-hardenable superalloy. It has the high strength and good weldability of the widely used INCONEL alloy 718 but with greatly improved machinability. During development of alloy 706, it was found that rupture ductility could be improved by a $1550^{\circ} \mathrm{F}$ treatment prior to the final age-hardening treatment. This treatment, however, had a varied effect on room-temperature yield strength. The effect seemed to depend on very small differences in aluminum content.

Material directly aged without the $1550^{\circ} \mathrm{F}$ treatment had high yield strength at low aluminum contents, and yield strength decreased as aluminum content was increased up to about $0.65 \%$. With the $1550^{\circ} \mathrm{F}$ preage treatment, however, material with low aluminum content had low yield strength, and yield strength increased with increasing aluminum up to about $0.4 \%$.

To explain these changes in yield strength, a laboratory investigation was performed to study the effects of aluminum content and heat treatment on the properties and structure of a11oy 706 .

*INCONEL is a Registered Trademark of The International Nickel Company, Inc. 


\section{EXPERIMENTAL PROCEDURE}

Six different experimental heats were produced with aluminum contents ranging from $0.033 \%$ to $0.90 \%$. The material was vacuum melted and forged to $9 / 16-i n$. square bars.

Four different heat treatments were selected for study. The treatments are described in Table 1. It was later determined that the optimum annealing temperature for commercial treatments would be 1700 to $1850^{\circ} \mathrm{F}$ instead of the $1950^{\circ} \mathrm{F}$ used for this study. The results, however, are essentially the same for both treatments. The commercial direct-age treatment (Treatment A) was also later changed to $1350^{\circ} \mathrm{F}$ from the $1325^{\circ} \mathrm{F}$ shown here. The higher aging temperature improves tensile properties.

Room-temperature tensile tests were performed on material from each of the six heats in each of the four conditions. Yield strength was plotted as a function of aluminum content for each heat treatment.

Residues of gamma prime, the precipitation-hardening phase in the a11oy, were prepared by dissolving the specimens electrolytically in $20 \% \mathrm{H}_{3} \mathrm{PO}_{4}$. The percent gamma prime in the sample was estimated by measuring the weight of sample dissolved and the weight of residue recovered.

The gamma prime residues were analyzed by $\mathrm{X}$-ray diffraction, $\mathrm{X}$-ray emission spectroscopy, and wet chemical methods. The structure of the gamma prime was established by X-ray diffraction. Thin-foil electron microscopy was also used to study the gamma prime structure. The aluminum contents of the residues were established by wet chemical analysis. method.

Elastic modulus was determined for the material by the dynamic

Table 1 - Heat Treatments Studied

\begin{tabular}{|c|c|c|c|}
\hline Designation & Annea1 & Intermediate & Age \\
\hline Treatment A & $1950^{\circ} \mathrm{F} / \frac{1}{2} \mathrm{hr}, \mathrm{A} . \mathrm{C}$. & - & $\begin{array}{l}1325^{\circ} \mathrm{F} / 8 \mathrm{hr}, \mathrm{F} . \mathrm{C} \\
100^{\circ} \mathrm{F} / \mathrm{hr} \text { to } 1150^{\circ} \mathrm{F} / \\
8 \mathrm{hr}, \mathrm{A} . \mathrm{C} \text {. }\end{array}$ \\
\hline Treatment B & $1950^{\circ} \mathrm{F} / \frac{1}{2}$ hr, A.C. & $1550^{\circ} \mathrm{F} / 3 \mathrm{hr}, \mathrm{A} . \mathrm{C}$. & $\begin{array}{l}1325^{\circ} \mathrm{F} / 8 \mathrm{hr}, \mathrm{F} . \mathrm{C} . \\
100^{\circ} \mathrm{F} / \mathrm{hr} \text { to } 1150^{\circ} \mathrm{F} / \\
8 \mathrm{hr}, \mathrm{A} . \mathrm{C} \text {. }\end{array}$ \\
\hline Treatment C & $1950^{\circ} \mathrm{F} / \frac{1}{2} \mathrm{hr}$, A.C. & $1550^{\circ} \mathrm{F} / 3 \mathrm{hr}$, A.C. & - \\
\hline Treatment D & $1950^{\circ} \mathrm{F} / \frac{1}{2} \mathrm{hr}$, A.C. & - & - \\
\hline
\end{tabular}




\section{RESULTS AND DISCUSSION}

Chemical compositions of the six experimental heats are 1 isted in Table 2. The variations in yield strength with heat treatment of these compositions are shown in Figure 1.

During the development of INCONEL alloy 706, most tensile testing was done on material given Treatment A (anneal and direct age). This stemned from prior experience with a similar alloy, INCONEL alloy 718. As shown in Figure 1 , the yield strength of materia1 given Treatment A decreases as the aluminum content increases, at least to the $0.65 \% \mathrm{Al}$ level. This trend is similar to that for solution-treated and aged INCONEL a11oy $718(1)$.

Subsequently, it was found that the $1200^{\circ} \mathrm{F}$ rupture ductility of a Tloy 706 was highly dependent on the alloy's thermomechanical history. Through experimentation, it was found that a $1550^{\circ} \mathrm{F} / 3 \mathrm{hr}$ treatment between the anneal and age would largely eliminate any problem of low rupture ductility. This resulted in Treatment B. As can be seen from the curve for Treatment B in Figure 1, the relationship of yield strength to aluminum content was allered by this treatment. Yield strength does not decrease sharply with increasing aluminum content.

The reasons behind the difference in behavior between material given Treatment A and that given Treatment B can best be visualized through use of the pictorial presentation by Kelly and Nicholson(2) in Figurc 2. In precipitation-hardened alloy 706 , as in most other precipitationhardened alloys, the gamma prime particles can be sheared by the moving dislocations, or the dislocations can bulge between the particles. The shear stress necessary to shear the gamma prime is given by

$$
\tau_{\mathrm{C}}=\frac{\pi}{2} \frac{\alpha_{\mathrm{R}}}{\mathrm{DB}}
$$

Table 2 - Chemical Compositions, \%, of Experimental Heats

\begin{tabular}{l|c|c|c|c|c|c}
\hline Elcment & Heat 1 & Heat 2 & Heat 3 & Heat 4 & Heat 5 & Heat 6 \\
\hline Aluminum & 0.033 & 0.12 & 0.20 & 0.44 & 0.65 & 0.90 \\
Nicke1 & 40.53 & 40.16 & 40.25 & 40.26 & 40.20 & 40.88 \\
Chromium & 16.33 & 17.00 & 16.62 & 16.79 & 16.49 & 16.85 \\
Iron & Ba1. & Ba1. & Bal. & Ba1. & Ba1. & Ba1. \\
Columbium* & 3.12 & 3.09 & 3.05 & 3.08 & 3.06 & 3.10 \\
Titanium & 2.01 & 1.99 & 2.02 & 2.00 & 2.05 & 2.07 \\
Carbon & 0.02 & 0.03 & 0.04 & 0.05 & 0.04 & 0.03 \\
& & & & & & \\
\hline
\end{tabular}

*Includes tantalum. 


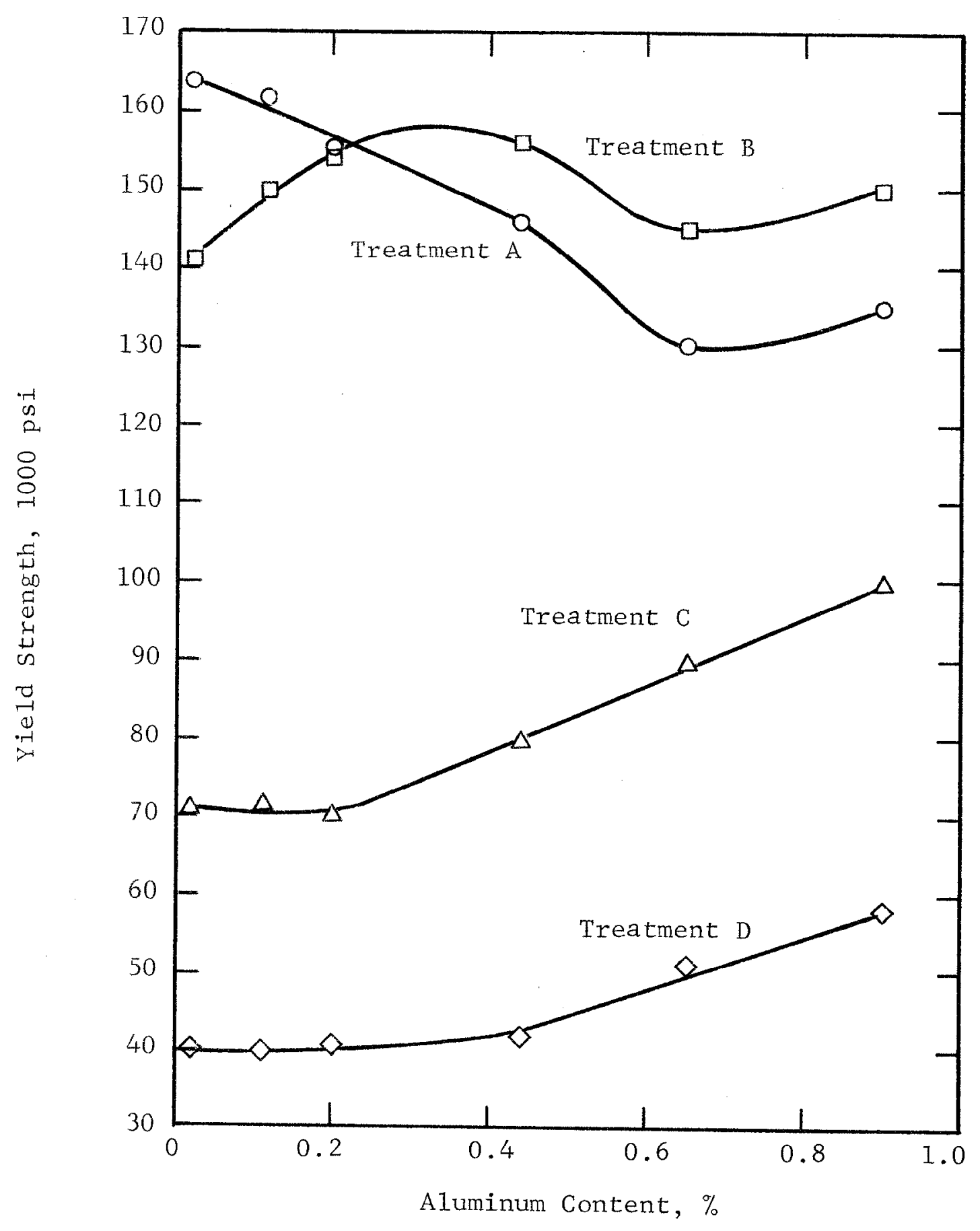

Figure 1 - Variation of yield strength with heat treatment and aluminum content. 


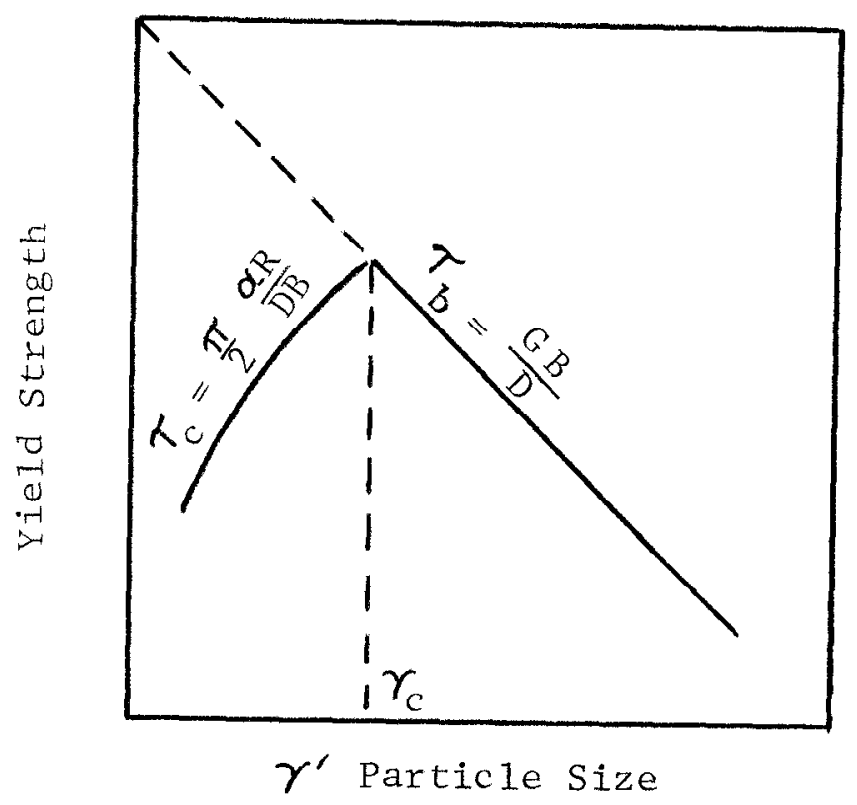

Figure 2 - Yield strength as a function of gamma prime particle size. 
where

$$
\begin{aligned}
& \pi=\text { constant } \\
& R=\text { radius of gamma prime particle } \\
& D=\text { distance between gamma prime particles } \\
& \alpha=\text { function of gamma prime properties such as } \\
& B=\text { internal order, misfit with matrix, etc. }
\end{aligned}
$$

The shear stress necessary to force a dislocation to bulge between the gamma prime is

$$
\tau_{\mathrm{B}}=\frac{\mathrm{GB}}{\mathrm{D}}
$$

where

$$
\begin{aligned}
& \mathrm{G}=\text { shear modulus of matrix } \\
& \mathrm{B}-\text { Burger's vector } \\
& \mathrm{D}=\text { distance between gamma prime particles }
\end{aligned}
$$

Equating the above two stresses yields the critical gamma prime particle size and distribution for maximum shear stress. If the material is slightly underaged, the critical shear stress is largely dependent on the properties of the gamma prime particles. If the material is overaged, the shear strength is more dependent on matrix shear modulus and interparticle spacing.

\section{Evaluation of Direct-Age Treatment}

The anneal and direct age (Treatment A) leaves alloy 706 in the slightly underaged condition. The gamma prime particles are sheared by the dislocations, and yield strength is basically a function of the particle properties. Examination of the gamma prime structure variation as a function of aluminum content reveals, as shown in Figures 3 and 4, that at a low aluminum 1eve1 (Heat 1) the gamma prime is body-centered tetragonal (BCT). As the aluminum content of the alloy is increased, face-centered-cubic (FCC) gamma prime becomes the predominant structure, and the lattice parameter decreases as shown in Figure 4. In Figure 3 , the splits in the (200) and (400) diffraction peaks indicate a tetragonal structure for the gamma prime in Heat $1(0.033 \% \mathrm{Al})$. These same peaks are not split for the gamma prime in Heat $4(0.44 \%$ Al) indicating that the gamma prime is face-centered cubic. Further evidence that this structural change takes place in direct-aged material is provided by the selected-area diffraction patterns in Figures 5 and 6 .

The $\mathrm{Ni}_{3} \mathrm{Al}-\mathrm{Ni}{ }_{3} \mathrm{Cb}$ psuedo binary phase diagram of Figure 7 shows that the solubility of aluminum in orthorhombic $\mathrm{Ni}{ }_{3} \mathrm{Cb}$ is very low, and that $\mathrm{Ni}_{3} \mathrm{Al}$ will precipitate at low aluminum levels. Since the metastable BCT $\mathrm{Ni}_{3}^{3} \mathrm{Cb}$ is less stable than the orthorhombic form, it follows that even less aluminum would be soluble in BCT gamma prime.

As the aluminum content of the alloy is increased above the $0.65 \%$ leve1, the lattice parameter of the gamma prime seems to stabilize, and yield strength increases because of the greater amount of gamma prime 

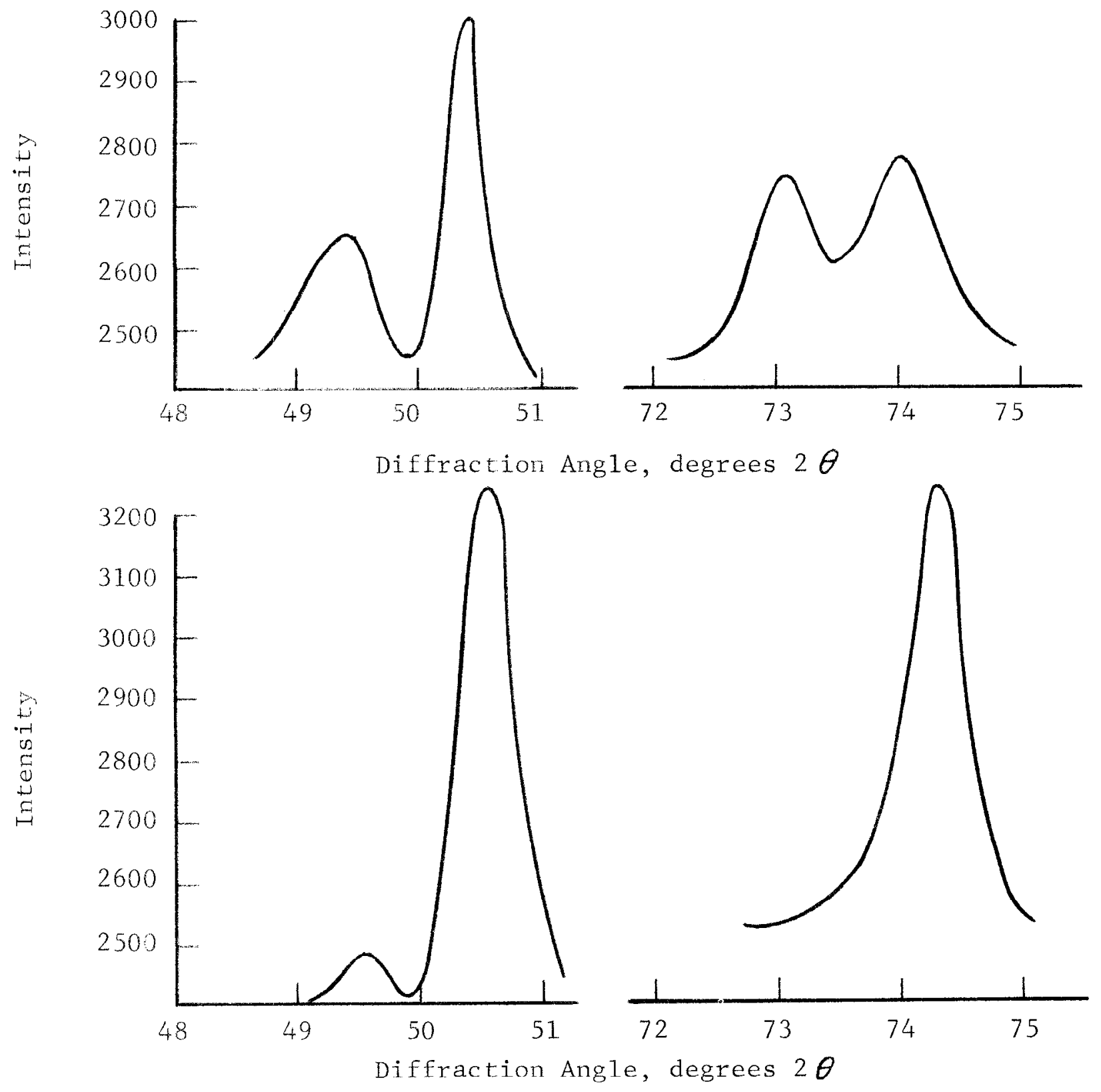

Figure 3 - X-ray diffraction peaks from gamma prime residues. Top: Heat 1 with Treatment B. Bottom: Heat 4 with Treatment B. 


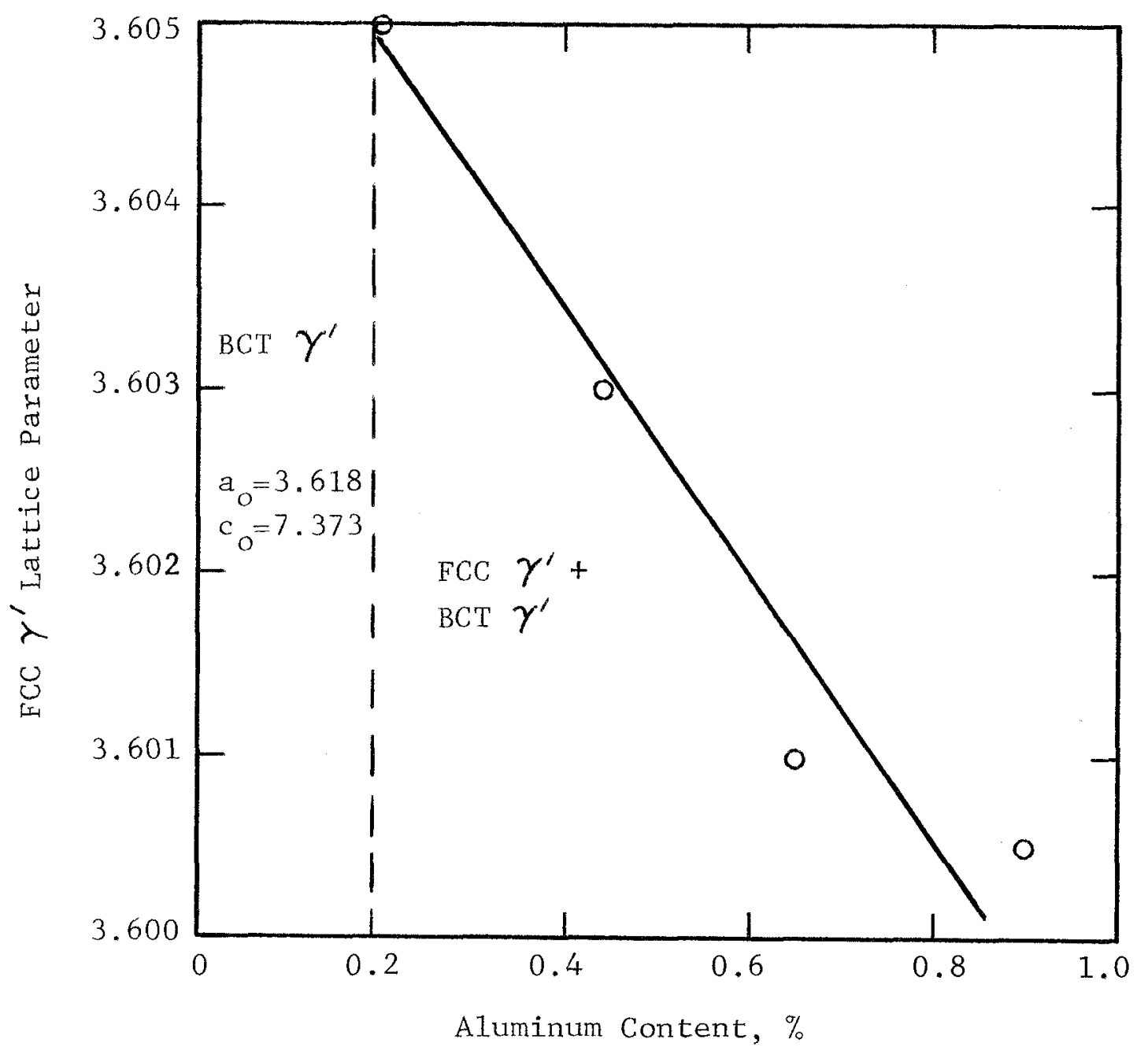

Figure 4 - Variation of latticc parameter with aluminum content for face-centered-cubic gamma prime. 


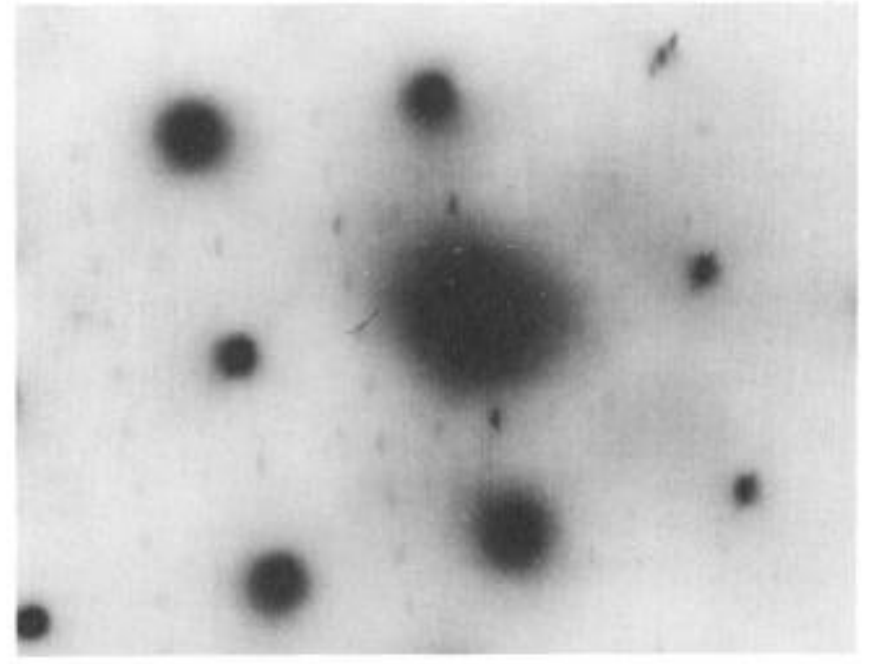

Figure 5 - Selected-area diffraction pattern of Heat 1 given Treatment A. Superlattice spots indicate the presence of BCT gamma prime. 


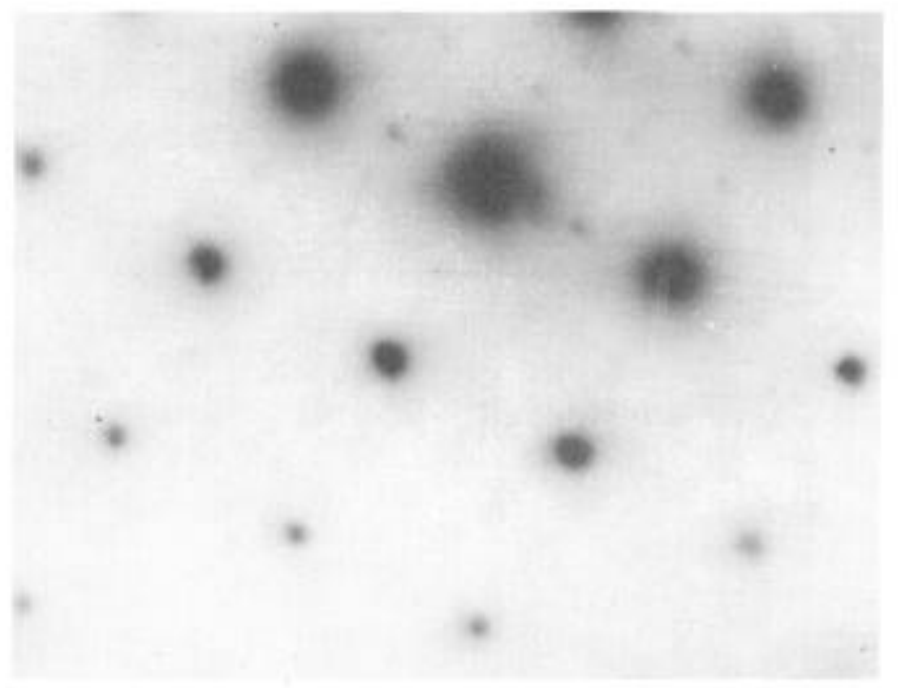

Figure 6 - Selected-area diffraction pattern of Heat 4 given Treatment A. Superlattice spots indicate FCC gamma prime. 


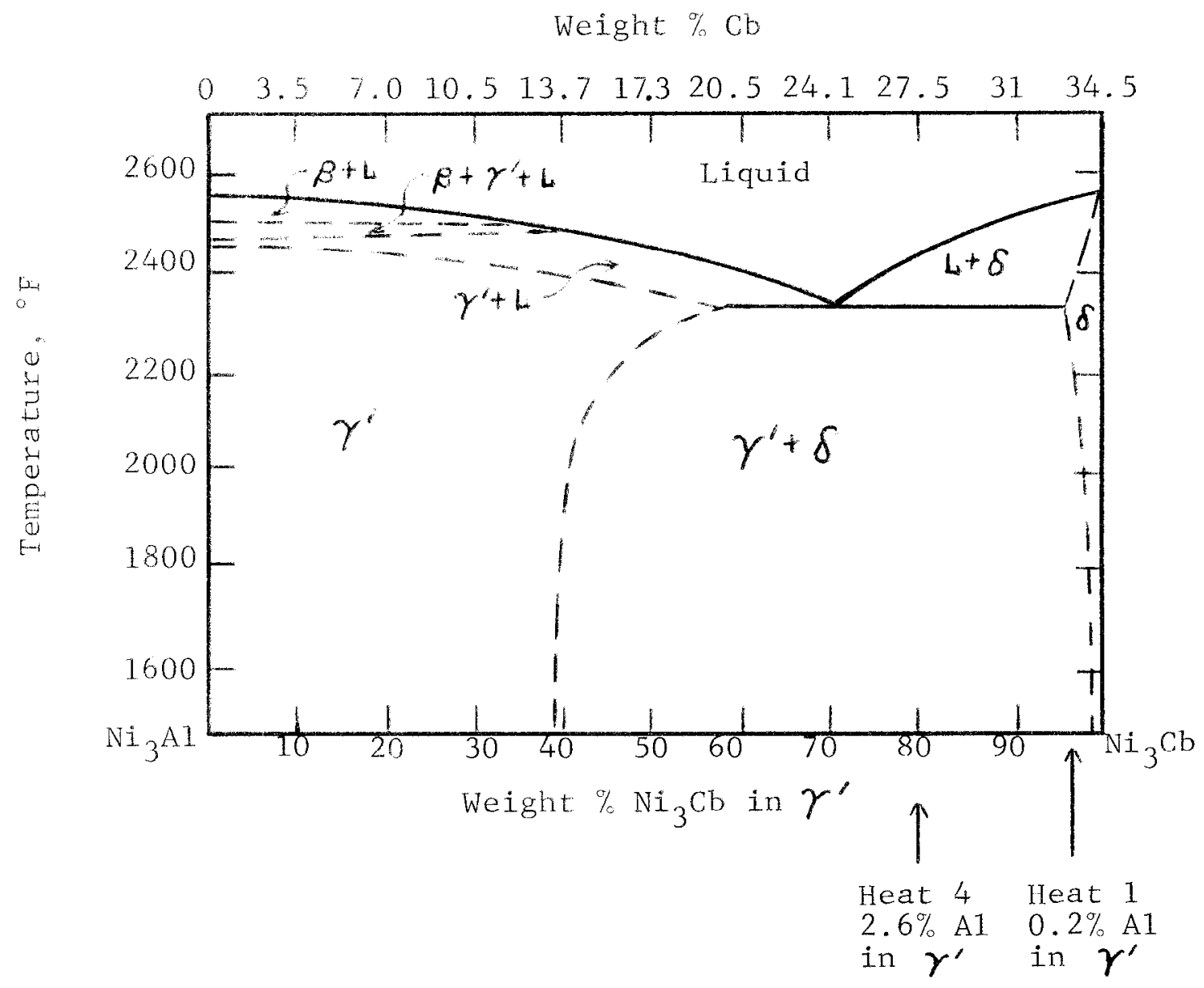

Figure $7-\mathrm{Ni}_{3} \mathrm{Al}-\mathrm{Ni}_{3} \mathrm{Cb}$ pseudo binary diagram. 
formed.

If the amount of gamma prime precipitated is neglected, the change in yield strength as a function of aluminum content can be visualized as shown in Figure 8 . This family of curves illustrates the effect of changing the internal order or lattice parameter of the gamma prime. The curves show that as the structure changes from BCT to FCC and as the lattice parameter of FCC gamma prime decreases:

(1) the level of $\alpha$ decreases

(2) the critical gamma prime particle size increases

(3) the maximum yield strength decreases

The above effects indicate that the maximum yield strength of directaged material would be obtained with the lowest aluminum content. That this does in fact occur was shown in Figure 1. The change in $\alpha$ as the gamma prime structure changes from ordered FCC to ordered BCT is probably due to the change in superdislocation movement through the two types of gamma prime.

Nevitt (3) described the stacking arrangement of atoms in the two structures as presented in Table 3 and Figure 9. Figures 10 and 11 show the unit cells of the two structures. Neglecting ordering, both can be roughly described as face-centered cubic. Including the effect of ordering changes the description of the $\mathrm{Ni}_{3} \mathrm{Cb}$ gamma prime to bodycentered tetragonal, with the $c_{0}$ parameter roughly equal to twice the $a_{0}$
parameter.

Table 3 - Stacking Arrangements in Close-Packed Ordered $\mathrm{A}_{3} \mathrm{~B}$ Structures*

\begin{tabular}{c|c|c|c}
\hline $\begin{array}{c}\text { Structure } \\
\text { Type }\end{array}$ & $\begin{array}{c}\text { Nickc1 } \\
\text { Compound }\end{array}$ & $\begin{array}{c}\text { Layer } \\
\text { Type }\end{array}$ & $\begin{array}{c}\text { Stacking } \\
\text { Sequence }\end{array}$ \\
\hline $\mathrm{Cu}_{3} \mathrm{Au}$ & $\mathrm{Ni}_{3} \mathrm{Al}$ & $\mathrm{A}$ & abcabc \\
$\mathrm{Ni}_{3} \mathrm{Ti}$ & $\mathrm{Ni}_{3} \mathrm{Ti}$ & $\mathrm{A}$ & abacabac \\
$\mathrm{Cd}_{3} \mathrm{Mg}$ & - & $\mathrm{A}$ & abab \\
$\mathrm{Al}_{3} \mathrm{Pu}$ & - & $\mathrm{A}$ & abcacbabcacb \\
$\mathrm{Cu}_{3} \mathrm{Ti}$ & $\mathrm{Ni}_{3} \mathrm{Cb}$ & $\mathrm{B}$ & abab** \\
$\mathrm{Al}_{3} \mathrm{Ti}$ & $\mathrm{Ni}_{3} \mathrm{~V}$ & $\mathrm{~B}$ & abcdef** \\
&
\end{tabular}




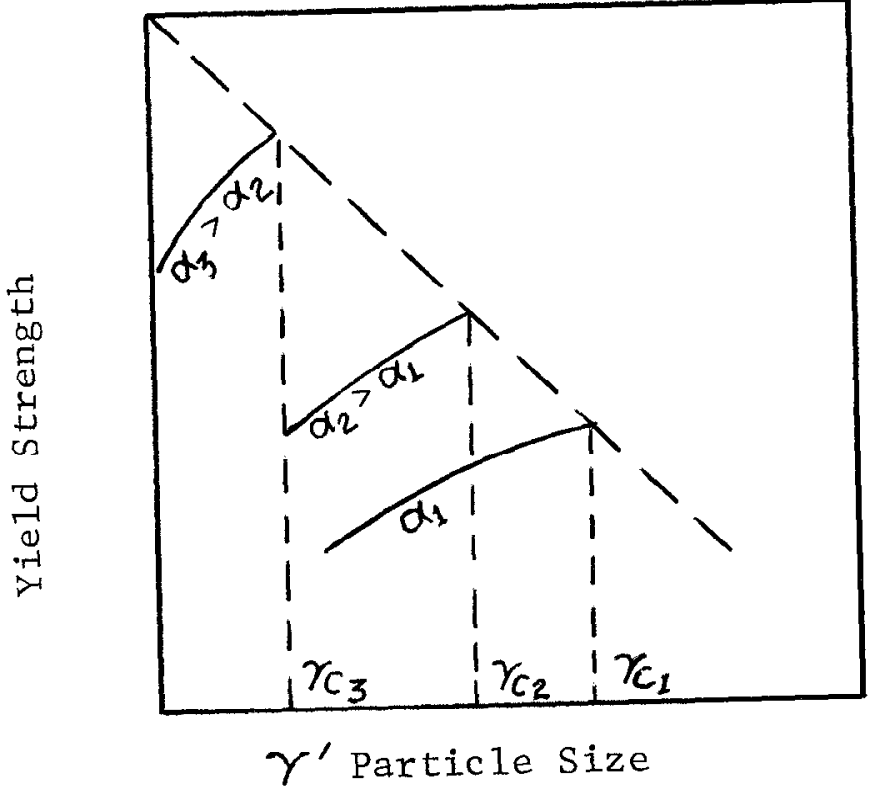

Figure 8 - Yield strength as a function of gamma prime particle size, particle effectiveness, and supersaturation. 


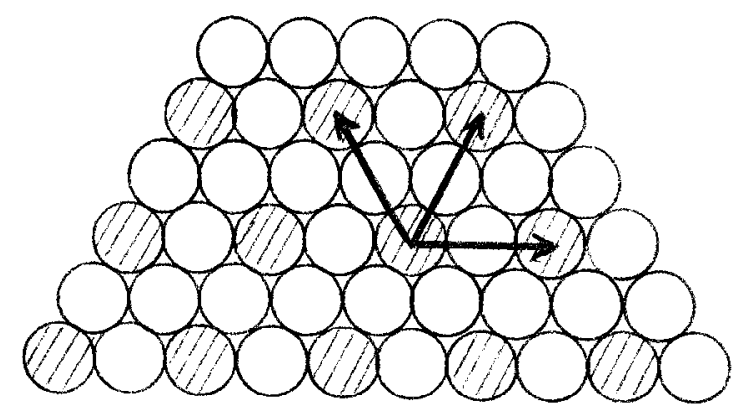

Layer A

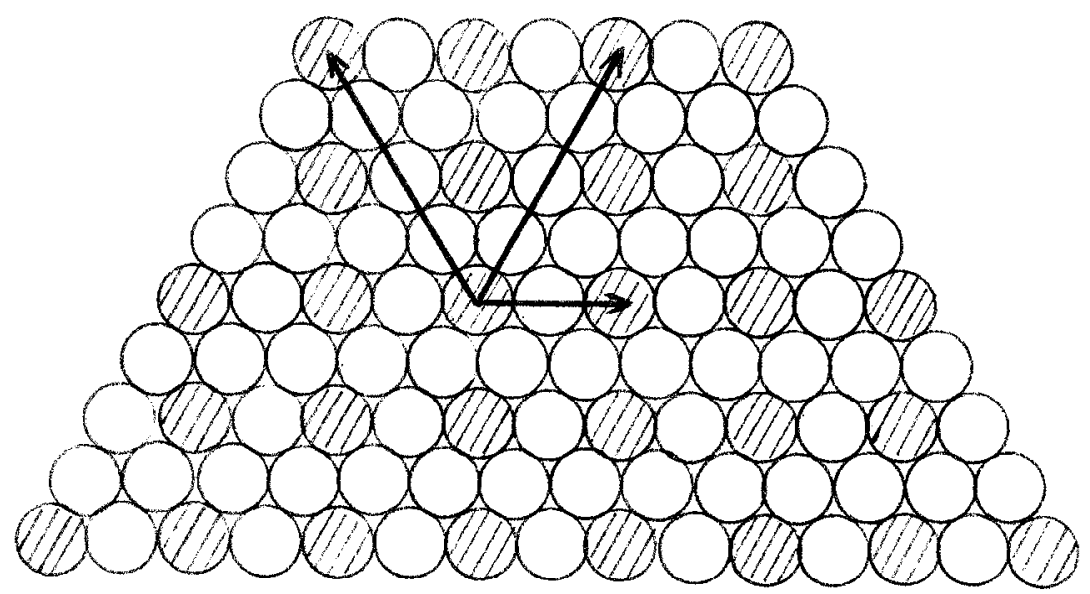

Layer B

Figure 9 - Close-packed ordered layers in $\mathrm{A}_{3} \mathrm{~B}$ phases. Top: $\mathrm{Ni}_{3} \mathrm{Al}$. Bottom: $\mathrm{Ni}_{3} \mathrm{~V}$. 


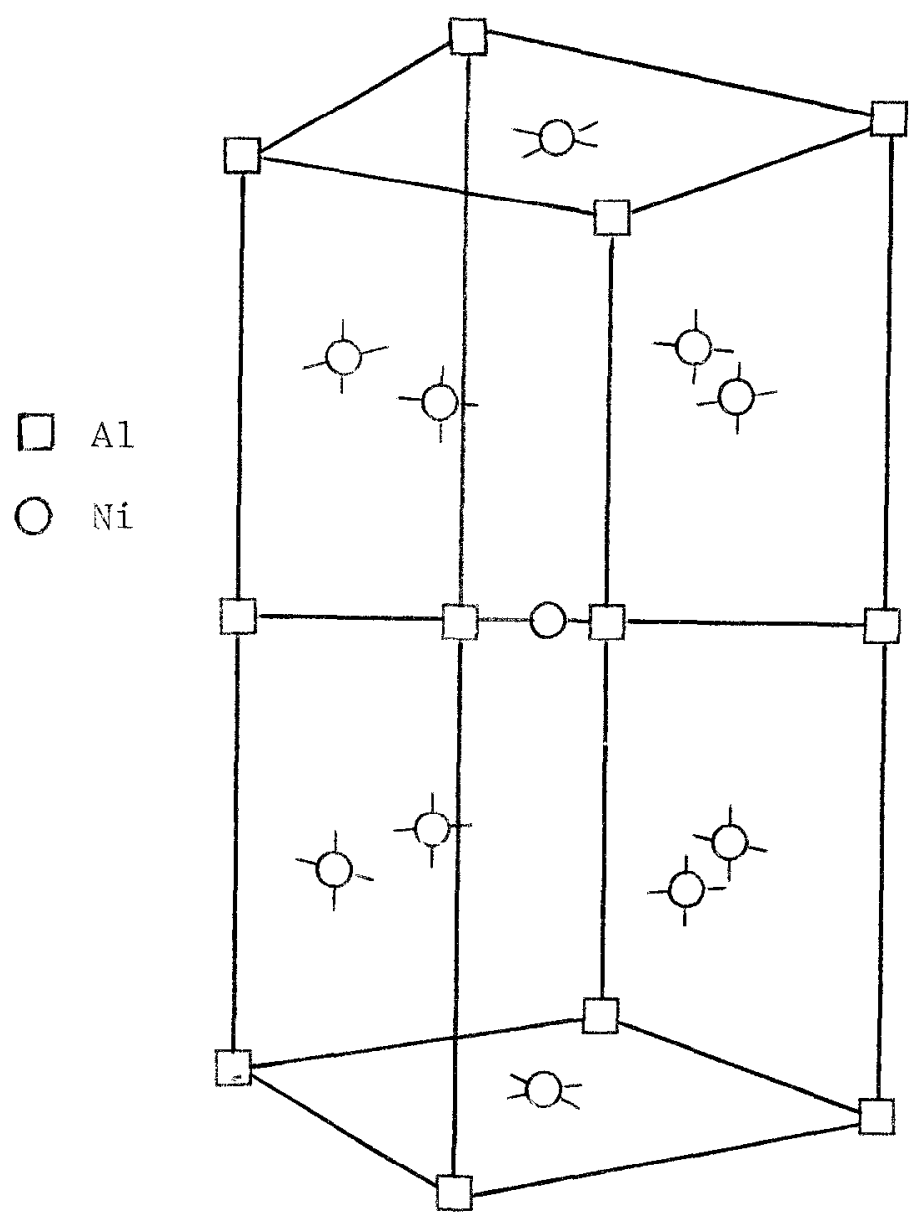

Figure 10 - Two unil cells of face-centeredcubic $\mathrm{Ni}_{3} \mathrm{Al}$ gamma prime. 


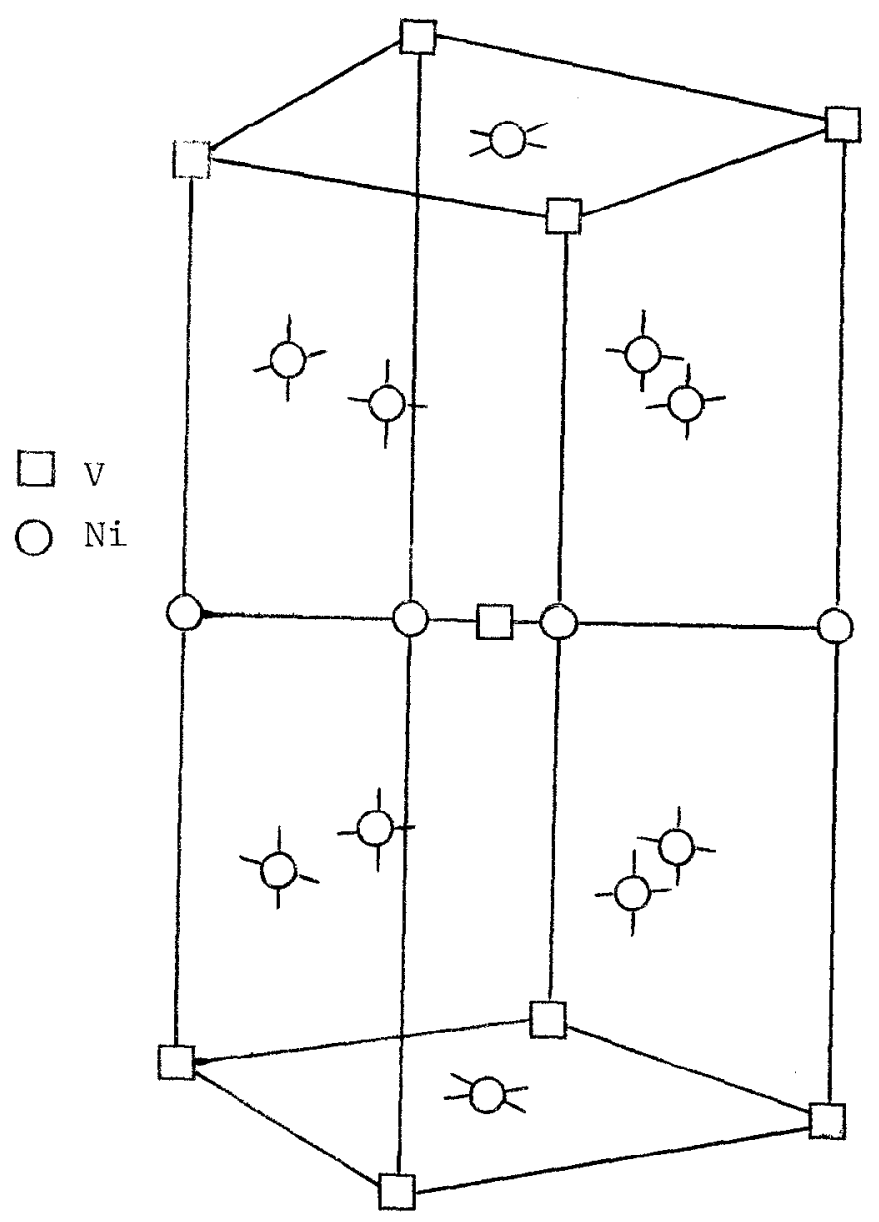

Figure 11 - Unit cell of body-centeredtetragonal $\mathrm{Ni}_{3} \mathrm{~V}$ structure. 
Figure 9, which shows the arrangement of atoms in the close-packed planes, illustrates the effect of internal order of the gamma prime on the superdislocation arrangement. A superdislocation consisting of two a/2 <110> matrix dislocations restores order in the FCC gamma prime regardless of which of the three $\langle 110\rangle$ directions shown in Figure 9 the superdislocation moves. This is not true for the BCT lattice. In two of the three directions, as has been shown by others (4), the superdislocation must consist of four a/2 <110> matrix dislocations.

This change in superdislocation structure is probably the major reason why such high strength can be obtained with INCONEL alloys 706 and 718 without destroying other attributes such as weldability. It allows higher strength with lower supersaturation.

\section{Evaluation of Intermediate Treatment}

The results obtained for direct-aged material, when applied to material given Treatment B, imply that the $1550^{\circ} \mathrm{F} / 3 \mathrm{hr}$ plus age treatment overages the alloy. Yield strength would then depend on matrix shear modulus and interparticle spacing of the gamma prime.

Figure 1 shows yield strength as a function of aluminum content for material given Treatments B, C, and D. Morphology of the gamma prime in samples of two different aluminum contents given Treatment $B$ is shown in Figures 12 and 13 .

In the annealed condition (Treatment D), yield strength should vary with modulus of elasticity. A comparison of yield strength (Figure 1) with the modulus values plotted in Figure 14 shows that this is true for the annealed samples.

For samples given Treatment $C$ (anneal plus intermediate treatment only), yield strength should again follow the modulus, but be higher than the annealed samples because of the gamma prime precipitated during the $1550^{\circ} \mathrm{F}$ intermediate treatment. In this case, the gamma prime acts like a dispersoid, and the dislocations bulge between the particles. Again, the data in Figures 1 and 14 show the expected trend. At low aluminum levels (Heats 1, 2, and 3), it appears that the higher modulus offsets the lower amount of gamma prime present. As the aluminum content increases, both the modulus and the amount of gamma prime precipitated cause the increase in yield strength shown.

For samples given Treatment B (anneal plus intermediate treatment plus age), yield strength is still highly dependent on modulus as shown by the data for that treatment in Figures 1 and 14. The modulus variation for alloy 706 given Treatment $B$ is identical to that for the alloy given Treatment A. The basic difference between the two conditions is that with Treatment B the yield strength is a function of the modulus with the gamma prime acting as a dispersoid, whereas with Treatment $A$ the yield strength is a function of the gamma prime properties.

\section{CONCLUSIONS}

Heat treatments for INCONEL alloy 706 provide both high tensile properties and good stress-rupture properties. Yield strength of the alloy is affected by gamma prime structure, which is controlled by aluminum content. 


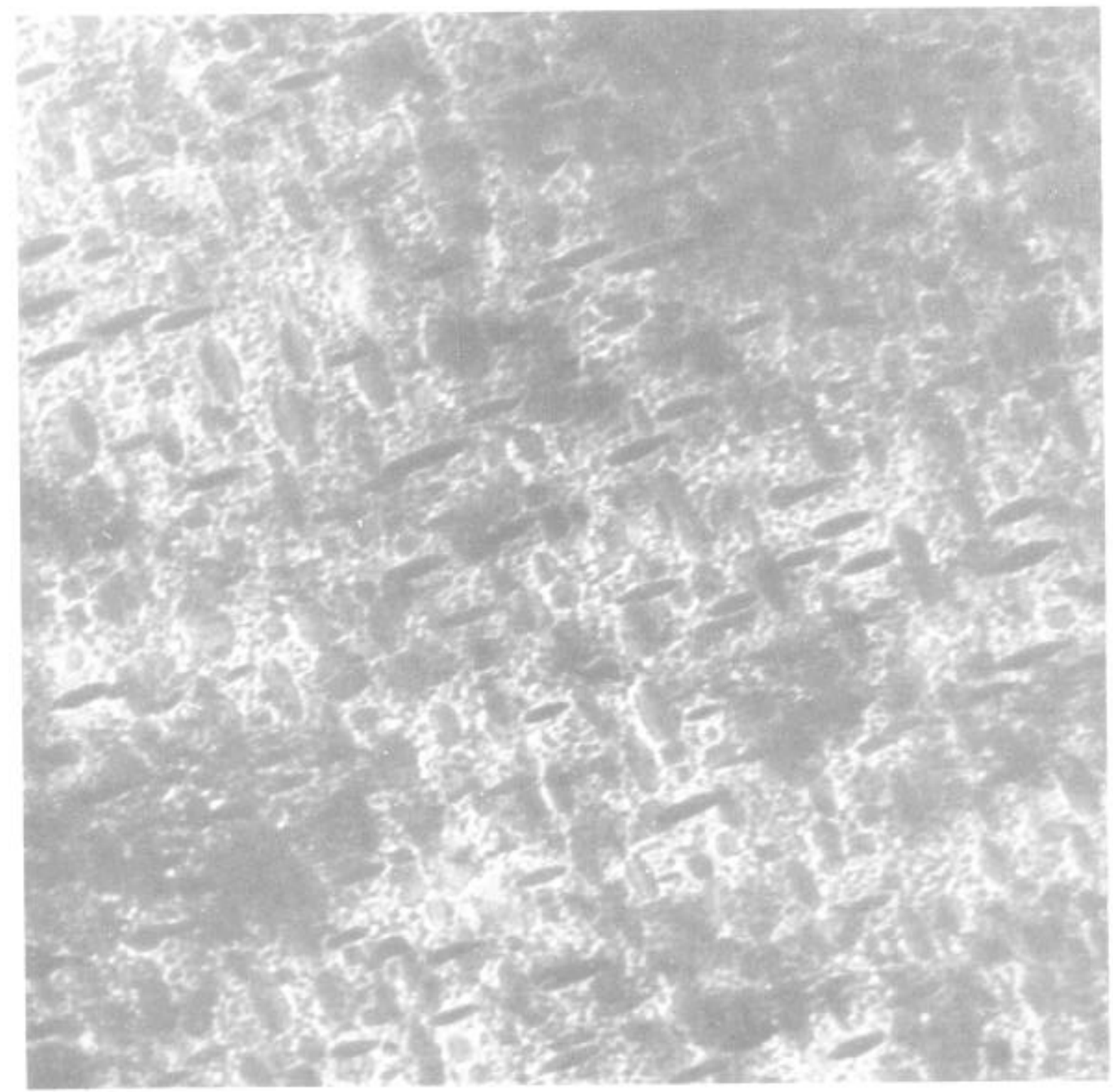

Figure 12 - Thin foil $(40,000 \mathrm{X})$ of Heat 1 given Treatment B. The gamma prime has a disc-shaped morphology and is body-centered tetragonal. 


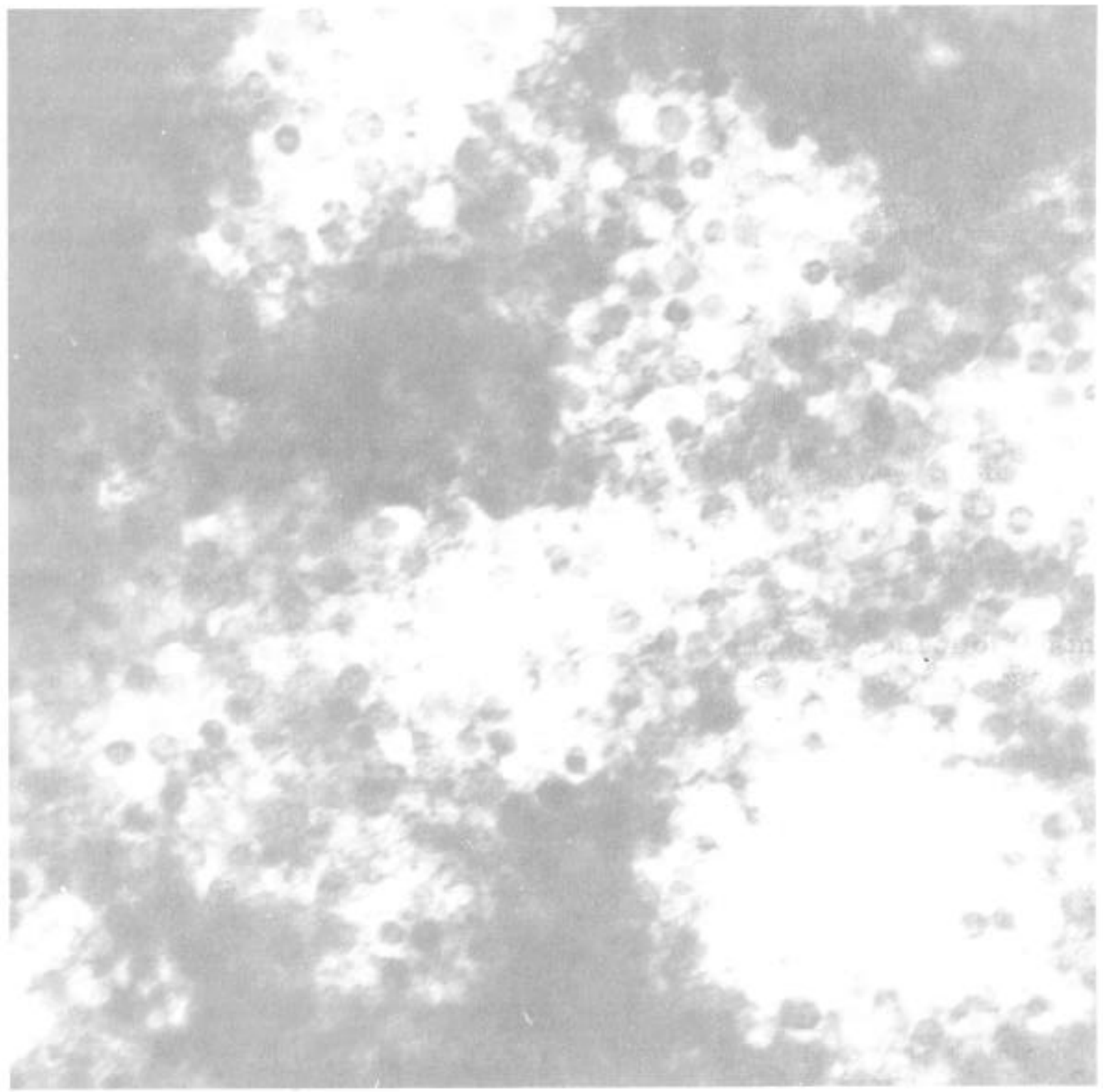

Figure 13 - Thin foil $(40,000 \mathrm{x})$ of Heat 4 given Treatment B. The gamma prime has a spherical morphology and is face-centered cubic. 


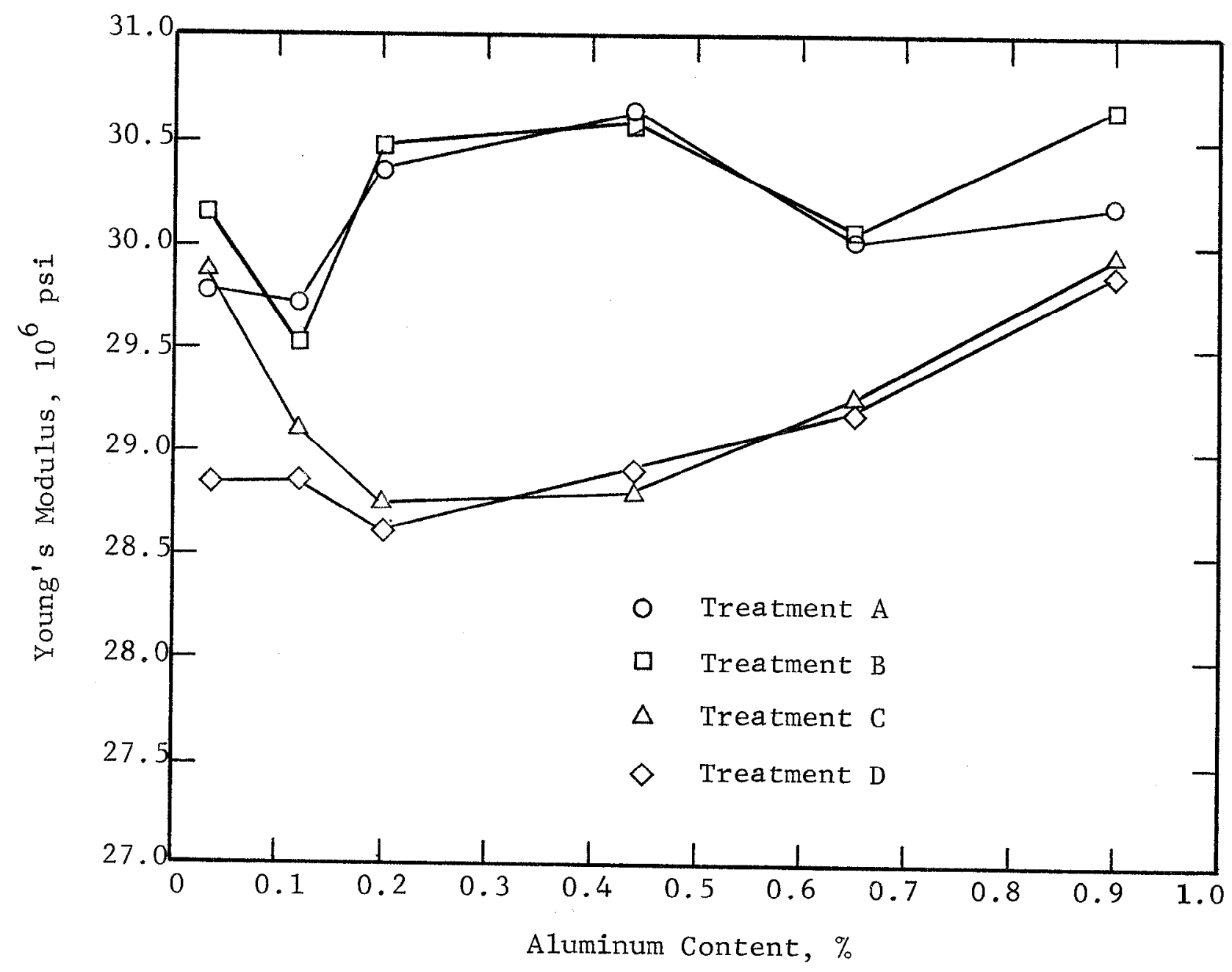

Figure 14 - Variation of modulus of elasticity with aluminum content. 
The direct-age treatment leaves the a11oy in a slightly underaged condition. Yield strength of underaged material is a function of gamma prime particle properties. At low aluminum contents, the structure of the gamma prime is body-centered tetragonal. As the aluminum content increases, the gamma prime structure changes to face-centered cubic. A higher maximum yield strength is obtainable with the body-centered tetragona1 structure.

The $1550^{\circ} \mathrm{F}$ intermediate treatment plus age hardening overages the alloy. The yield strength of overaged material is not a function of gamma prime properties, but depends instead on matrix shear modulus and interparticle spacing of the gamma prime.

\section{ACKNOWLEDGMENTS}

The authors wish to acknowledge the contributions of E. F. Clatworthy, who performed the mechanical tests, and C. J. Sponaugle, who provided the measurements of elastic modulus.

\section{REFERENCES}

1. H. L. Eiselstein. "Advances in Technology of Stainless Steels and Related Alloys", Special Technical Publication No. 369, American Society for Testing and Materials, 1965.

2. A. Kelly and R. B. Nicholson. Precipitation Hardening, Progress in Materials Science Series, Vol 10 (New York: Macmillan, 1963) p 379.

3. M. V. Nevitt. Electronic Structure and Alloy Chemistry of the Transition Elements, ed. by P. A. Beck (New York: Interscience, 1963) p 169.

4. I. Kirman and D. H. Warrington. "The Precipitation of $\mathrm{Ni}_{3} \mathrm{Cb}$ Phases in a Ni-Fe-Cr-Nb Ailoy", Metaliurgical Transactions, Vo1 1 (1970) p 2682 . 